\title{
PEMANFAATAN INTERNET OLEH MAHASISWA DALAM MENGHADAPI MASYARAKAT EKONOMI ASEAN
}

\author{
Lilik Indrawati \\ Program Studi Manajemen \\ Fakultas Ekonomi Universitas Katolik Darma Cendika \\ Jalan Dr. Ir. H. Soekarno 201, Surabaya
}

\begin{abstract}
The education process is basically the transfer of information. The rapid development of information technology have an impact on human life, especially education. Its positive impact is closely linked to improved quality of life. Information facing ASEAN Economic Community (AEC) is so easily obtained either through the mass media, electronics, as well as through a network of internet technology. The Internet is a network of information, communication, and various sources are not infinite number of which can be used to help users produce a final project, thesis, thesis, dissertation, project work, and so on. Internet as a tool for achieving information on a global scale. Users can now obtain more information than what is contained in the textbooks by searching and accessing all websites around the world. Especially for the students, with the internet which is easily accessible anywhere, using either WIFI or a particular provider, making it easier for students to obtain data or news from domestic and foreign news. Students may also work on assignments, tests, and develop materials that have been received in the lecture. Thus, more extensive knowledge of students.
\end{abstract}

\begin{abstract}
ABSTRAK
Proses pendidikan pada dasarnya adalah perpindahan informasi. Pesatnya perkembangan teknologi informasi ini membawa dampak bagi kehidupan manusia, terutama dunia pendidikan. Dampak positifnya terkait erat dengan peningkatan kualitas kehidupan. Informasi menghadapi Masyarakat Ekonomi ASEAN (MEA) begitu mudah diperoleh baik lewat media massa, elektronik, maupun melalui jaringan teknologi internet. Internet merupakan jaringan informasi, komunikasi dan berbagai sumber yang tidak terhingga banyaknya yang dapat digunakan untuk membantu pengguna menghasilkan tugas akhir, skripsi, tesis, disertasi, kerja proyek, dan sebagainya. Internet sebagai alat untuk mencapai informasi dalam skala global. Pengguna kini dapat memperoleh informasi yang lebih daripada apa yang terdapat dalam buku teks dengan mencari dan mengakses semua website di seluruh dunia. Khusus untuk para mahasiswa, dengan adanya internet yang dengan mudah diakses di mana saja, baik menggunakan WIFI maupun provider tertentu, sehingga mempermudah para mahasiswa untuk memperoleh data ataupun berita dari dalam negeri maupun dari luar negeri. Mahasiswa juga dapat mengerjakan tugas, tes, maupun dalam mengembangkan
\end{abstract}


materi yang sudah diterima dalam perkuliahan. Dengan demikian, pengetahuan mahasiswa makin luas.

Keywords: internet, e-mail, ASEAN Economic Community.

\section{PENDAHULUAN}

Ekonomi global telah semakin menyatu dengan derasnya aliran barang, jasa, uang, sumber daya manusia dan data lintas batas negara. Asia Tenggara dapat memanfaatkan fenomena ini dengan implemetasi MEA (Masyarakat Ekonomi ASEAN) yang bertujuan untuk membentuk pasar tunggal yang terdiri dari 600 juta konsumen. Untuk mencapai tujuan tersebut, negara ASEAN harus meningkatkan produktivitas lintas sektor, termasuk sektor pendidikan. Pasalnya, menurut laporan dari Mckinsey Global Institute (2014) Asia Tenggara menghadapi tantangan dalam menghadapi hal-hal terkait dengan pendidikan, khususnya pendidikan bahasa Inggris. Laporan tersebut menyatakan bahwa sistem pendidikan sebaiknya menitikberatkan pada keterampilan yang diperlukan di era perekonomian digital, dengan fokus pada kemampuan digital dan kefasihan berbahasa Inggris, selain mengasah kemampuan analisis secara mendalam guna meningkatkan produktivitas.

Di era informasi seperti saat ini internet memegang peranan penting dalam segala aspek kehidupan manusia. Internet menjadi media yang banyak digunakan oleh kalangan mahasiswa untuk memenuhi kebutuhan informasi guna menunjang kebutuhan studi yang mereka tempuh maupun untuk menunjang aktivitas mereka. Hal ini terjadi karena pada dasarnya kebutuhan setiap individu sangatlah beraneka ragam, sehingga adanya kebutuhan inilah yang menimbulkan motif untuk menemukan informasi pada sebuah media yang paling dianggap tepat. Akibatnya muncul berbagai cara dan strategi untuk mendapatkan informasi tersebut. Dalam hal ini internet banyak digunakan karena menawarkan berbagai kemudahan untuk dapat mengakses berbagai literatur dan referensi ilmu pengetahuan yang sesuai dengan kebutuhan para akademisi.

Bagi para mahasiswa, penggunaan internet sebagai alat dalam menggali informasi yang berupa materi pembelajaran terkait dengan mata kuliah yang diberikan oleh perguruan tinggi. Hal ini akan dapat memicu sekaligus dapat meningkatkan motivasi mereka dalam mengikuti proses pembelajaran. Menurut Oetomo (2002: 5) ketersediaan informasi yang up-todate telah mendorong tumbuhnya motivasi untuk membaca dan mengikuti perkembangan ilmu pengetahuan dan teknologi (iptek) yang terjadi di berbagai belahan dunia.

\section{TINJAUAN PUSTAKA Pengertian Internet}

Internet merupakan perpaduan antara teknologi informasi dan teknologi komunikasi, memiliki fungsi yang sangat cocok sebagai sarana penyampaian bahan pengajaran. Di sisi lain internet didesain sebagai alat pengirim informasi dari suatu komputer ke komputer lain yang secara ideal, tanpa 
terhalang oleh faktor jarak (Nafisah, 2001).

Menurut Purbo (2000) dalam Nafisah (2001) saat ini ada sekitar 1000-2000 mailing list elektronik dari berbagai bidang di internet. Newsgroup (kelompok diskusi) merupakan konferensi secara elektronik yang dapat digunakan untuk kelas jarak jauh. Terdapat sekitar 30.000 newsgroup dalam berbagai bidang yang terdapat di internet. File Transfer Protocol (FTP) adalah pengambilan/transfer arsip atau file secara elektronik dari satu komputer ke komputer yang lain. Berbagai laporan penelitian dapat diambil dan disebarluaskan dengan menggunakan fasilitas ini.

Menurut Harefa (2000: 104) internet dapat membuat proses-proses pengajaran dan pelatihan menjadi jauh lebih "menyenangkan" dan jauh lebih mudah, karena berbagai informasi, data, dan pengetahuan dapat diperoleh secara instan, dalam hitungan detik atau dengan kecepatan orang berpikir (at the speed of thought), dan dengan biaya yang relatif jauh lebih murah. Bagi para siswa, penggunaan internet sebagai alat dalam menggali informasi yang berupa pendidikan, akan dapat memicu dan meningkatkan motivasi dalam proses pembelajaran mereka. Ketersediaan informasi yang up-todate telah mendorong siswa untuk membaca dan mengikuti perkembangan ilmu pengetahuan dan teknologi (iptek) yang terjadi di berbagai belahan dunia.

Interconnection Networking atau singkatannya lebih dikenal sebagai internet diartikan oleh Randall dan Latulipe sebagai suatu jaringan global yang terdapat di dalam jaringan komputer (Tjiptono dalam Nafisah, 2001: 2).

\section{Kerangka Berpikir}

Peranan motivasi sebagai moderasi pada pengaruh penggunaan internet sebagai peningkatan hasil nilai tugas dan tes. Motivasi belajar melalui penggunaan internet agar mahasiswa mampu meningkatkan pengetahuan internal dan eksternal dengan bagan sebagai berikut:

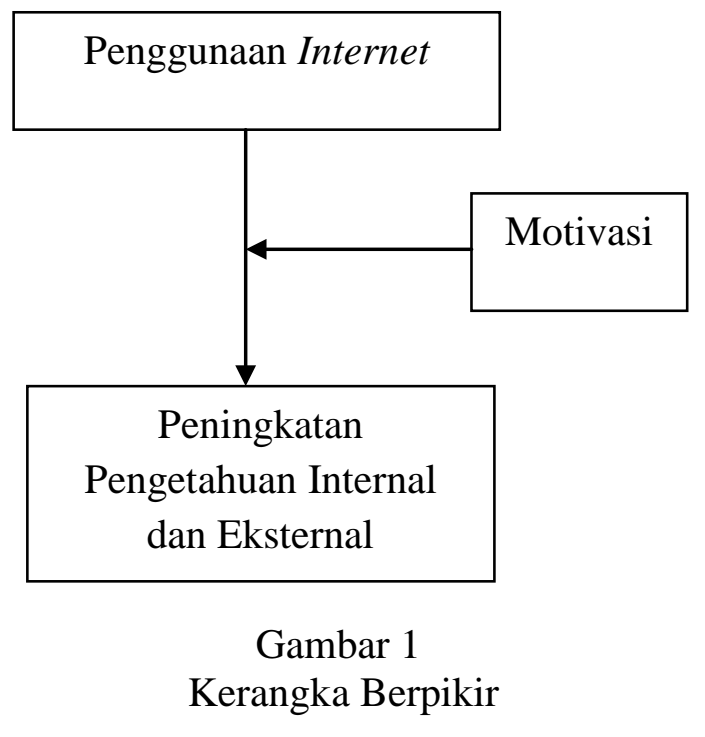

\section{Kebutuhan Informasi}

Kata kebutuhan dapat diartikan sebagai sesuatu yang harus dimiliki oleh seseorang. Belkin (1978) dalam Ishak (2006) dengan konsep Anomalous State of knowledge (ASK) memberikan batasan tentang kebutuhan informasi sebagai berikut: “....when $a$ person recognizes something wrong in his or her state of knowledge and wishes to resolve the anomaly“. Belkin (1978) dalam Ishak (2006) juga menyatakan bahwa kebutuhan informasi terjadi ketika seseorang menyadari adanya kekurangan dalam tingkat pengetahuannya tentang situasi atau topik tertentu dan berkeinginan mengatasi kekurangan tersebut. Sementara Derr dalam Novianto (2013) mengemukakan bahwa kebutuhan infor- 
masi merupakan hubungan antara informasi dan tujuan informasi seseorang, di mana ada suatu tujuan yang memerlukan informasi tertentu untuk mencapainya.

\section{Pengertian Motivasi}

Menurut Hariandja (2009: 322) motivasi diartikan sebagai faktor-faktor yang mengarahkan dan mendorong perilaku atau keinginan seseorang untuk melakukan suatu kegiatan yang dinyatakan dalam bentuk usaha yang keras atau lemah. Motif yang sangat kuat akan membentuk usaha yang keras. Selanjutnya, usaha memotivasi berarti memunculkan faktor-faktor (motif) yang mendorong orang berperilaku tertentu, yang dapat dilakukan dengan misalnya memberi imbalan, menciptakan persaingan, melatih, menasihati dan lain-lain.

Menurut Gitosudarmo dan Sudita (1997) dalam Ardana et al. (2009: 30) yang dimaksud motivasi adalah faktor-faktor yang ada dalam diri seseorang yang menggerakkan, mengarahkan perilakunya untuk memenuhi tugas tertentu. Motivasi menurut Handoko (2009: 251) merupakan kegiatan yang mengakibatkan, menyalurkan dan memelihara perilaku manusia. Motivasi menurut Winardi (2001: 132) adalah dorongan yang memberikan semangat kerja kepada para pegawai untuk berperilaku tertentu dalam usaha mencapai tujuan organisasi yang telah ditetapkan. Motivasi menurut Gomes (1995: 138) dalam Sulistiyani dan Rosidah (2009: 233) adalah keseluruhan proses pemberian dorongan/ rangsangan kepada para karyawan, sehingga mereka bersedia bekerja dengan rela tanpa dipaksa. Motivasi menurut Moekijat (2001: 5) berarti suatu daya pendorong atau perangsang untuk melakuan sesuatu. Menurut Simamora (2006: 456) motivasi adalah dorongan psikologis yang mengarahkan seseorang menuju sebuah tujuan. Motivasi melibatkan gerakan fisik dan mental.

Dari pendapat beberapa ahli tersebut dapat disimpulkan bahwa motivasi adalah dorongan yang dapat menyebabkan seseorang melakukan suatu usaha atau perilaku dengan suatu cara tertentu sebagai suatu pengekspresian dari kebutuhannya.

\section{Internet Sebagai Sumber Informasi}

Penggunaan internet telah menjadi sebuah gaya hidup (life style) bagi sebagian besar mahasiswa perguruan tinggi di seluruh dunia. Bagi mereka internet adalah sebuah alat fungsional yang telah mengubah cara seseorang berinteraksi dengan orang lain, maupun dalam menemukan informasi. Banyak di antara mahasiswa yang menggunakan internet untuk menyelesaikan berbagai kepentingan akademis, baik itu dilakukan melalui pertukaran e-mail dengan fakultas, teman sebaya, ataupun kepentingan lainnya. Di samping itu sebagian mahasiswa juga mengakses katalog online, database bibliografi, dan sumber informasi lainnya dalam bentuk grafik, teks, dan gambar melalui world wide web (www) (Bashir et al., 2008, dalam Novianto, 2013). Pernyataan yang sama juga dikemukakan oleh Sharma et al. (2006) dalam Novianto (2013) yang mengungkapkan bahwa mahasiswa menggunakan internet untuk mendapatkan informasi atau untuk keperluan penelitian. Kebanyakan dari mereka lebih menyukai internet karena dianggap sebagai sumber pengetahuan terbaru. Ishak (2006) menambahkan bahwa pengetahuan seseorang tentang 
sumber informasi (awareness of information sources) yang akan digunakan, seperti kecepatan akses (accessibility), kualitas (quality), ketepatan waktu (timeliness), kepercayaan (trustworthiness), kebiasaan (familiarty) dan keberhasilan sebelumnya (previous success) akan berdampak langsung pada pelaksanaan pencarian informasi (information is sought). Sehingga hal inilah yang mendorong seseorang untuk memilih media yang tepat sebagai sumber informasi bagi pemenuhan kebutuhannya.

\section{Fasilitas Internet}

Fasilitas internet: pemanfaatan internet mencakup seluruh fasilitas yang tersedia di internet termasuk penggunaan fasilitas search engine, relevansi, dan juga cara penelusuran/ pencarian informasi di internet. Menurut Purbo (2004) di antara keseluruhan fasilitas internet tersebut terdapat 5 aplikasi standar internet yaitu: www, e-mail, mailing list, FTP, newsgroup. Adapun kegunaan masing masing fasilitas tersebut adalah sebagai berikut :

a) WWW (World Wide Web). www merupakan kumpulan koleksi besar tentang berbagai macam dokumen yang tersimpan dalam berbagai server di seluruh dunia dan dokumen tersebut dikembangkan dalam format hypertext mark up language (html) yang memungkinkan terjadinya koneksi (link) dokumen yang satu dengan yang lainnya, baik dalam bentuk teks, visual, dan lain lain. www bersifat multimedia karena merupakan kombinasi teks, foto, dan grafika, audio, dan video. Dengan demikian www pada saat ini merupakan puncak pencapaian yang tidak mungkin dicapai oleh media-media yang tergabung di dalamnya secara sendiri-sendiri.

b) Elektronic mail/e-mail adalah suratmenyurat secara elektronik, di mana pesan yang dikirimkan akan sampai dalam waktu singkat. Pesan email tidak hanya berupa tulisan, tetapi dapat disertai dengan file gambar, suara, animasi, dan lain lain. Selain itu email dapat dikirimkan kepada ratusan orang hanya dalam satu kali pengiriman. Makanya, email menjadi penting untuk sarana berkomunikasi dalam zaman yang modern ini, dan terutama bagi para mahasiswa. E-mail merupakan fasilitas yang paling sederhana, paling mudah penggunaanya dan digunakan secara luas oleh para pengguna komputer.

c) Mailing list (milis). Mailing list merupakan perluasan e-mail. Dengan fasilitas ini pengguna yang telah memiliki alamat e-mail bisa tergabung dalam sebuah kelompok diskusi. Milis ini bisa digunakan diskusi untuk memecahkan permasalahan secara bersama-sama dengan saling memberikan saran pemecahan (brain storming). Komunikasi melalui milis ini memiliki sifat yang sama dengan e-mail yaitu bersifat tidak sinkron atau bersifat unreal time.

d) FTP (File Transfer Protocol). FTP adalah fasilitas internet yang memberikan kemudahan kepada pengguna untuk mencari dan mengambil arsip file (download file) di suatu server yang terhubungkan internet pada alamat tertentu yang menyediakan berbagai arsip (file), yang memang diizinkan untuk diambil oleh pengguna lain yang membutuhkannya. File ini bisa berupa hasil penelitan, artikel-artikel jur- 
nal. Di samping itu FTP juga dipergunakan meng-upload file materi situs (homepage), sehingga bisa diakses oleh pengguna di seluruh dunia.

e) Newsgroup. Newsgroup dalam internet adalah fasilitas yang digunakan untuk komunikasi antara dua orang atau lebih secara serempak dalam pengertian waktu yang sama (real time) dan dengan demikian berarti komunikasi adalah komunikasi yang sinkron. Bentuk pertemuan ini lazim disebut sebagai konferensi dan fasilitas yang digunakan bisa sepenuhnya multimedia (audio visual) dengan menggunakan fasilitas video conference, ataupun teks saja atau teks dan audio dengan menggunakan fasilitas IRC (Internet Relay Chat).

\section{ANALISIS HASIL PENELITIAN DAN PEMBAHASAN}

Penelitian dilakukan terhadap mahasiswa Fakultas Ekonomi Universitas Katolik Darma Cendika (UKDC), Surabaya. Ada 2 program studi yang dikelola Fakultas Ekonomi Universitas Katolik Darma Cendika (UKDC), Surabaya, yaitu Program Studi Akuntansi dan Program Studi Manajemen. Yang dijadikan obyek penelitian adalah seluruh mahasiswa dari 2 program studi ini.

Dari keseluruhan mahasiswa Fakultas Ekonomi Universitas Katolik Darma Cendika (UKDC), Surabaya diambil 191 mahasiswa sebagai sampel, yang terdiri dari 27 orang mahasiswa semester 1,36 orang mahasiswa semester 3, 104 orang mahasiswa semester 5 dan 24 orang mahasiswa semester 7. Mahasiswa yang dijadikan sampel diminta untuk mengisi kuesioner. Seluruh mahasiswa yang menjadi sam- pel mengisi kuesioner yang diberikan. Penelitian ini menunjukkan hasil-hasil sebagai berikut:

1. Dari 191 orang mahasiswa sampel, sebanyak 183 orang mahasiswa $(95,81 \%)$ meyatakan sudah menggunakan internet sebelum masuk kuliah di Fakultas Ekonomi Universitas Katolik Darma Cendika, Surabaya dan hanya 8 orang mahasiswa (4,19\%) yang menyatakan baru menggunakan internet setelah masuk kuliah di Fakultas Ekonomi Universitas Katolik Darma Cendika, Surabaya.

2. Dari 191 orang mahasiswa yang menjadi sampel, mahasiswa yang menyatakan sudah menggunakan internet $<1$ tahun sebanyak 32 orang mahasiswa $(16,75 \%)$, mahasiswa yang menyatakan telah menggunakan internet dari 1 tahun sampai dengan 2 tahun sebanyak 19 orang mahasiswa $(9,95 \%)$, mahasiswa yang menyatakan telah menggunakan internet lebih dari 2 tahun sampai dengan 3 tahun sebanyak 12 orang mahasiswa (6,28\%), mahasiswa yang menyatakan telah menggunakan internet lebih dari 3 tahun sampai dengan 4 tahun sebanyak 24 orang mahasiswa $(12,57 \%)$, mahasiswa yang menyatakan sudah menggunakan internet lebih dari 4 tahun sebanyak 103 orang mahasiswa (53,93\%) dan yang tidak mengisi 1 orang mahasiswa $(0,52 \%)$.

3. Dalam menggunakan internet, sebanyak 125 orang mahasiswa $(65,44 \%)$ menyatakan menggunakan perangkat komputer dan smartphone, sebanyak 53 orang mahasiswa $(27,75 \%)$ menyatakan menggunakan perangkat komputer dan modem dan sebanyak 13 
orang mahasiswa $(6,81 \%)$ menyatakan menggunakan komputer dan perangkat lainnya.

4. Dalam menggunakan internet, mahasiswa yang memanfaatkan layanan: free WIFI dari kampus dan dari kantor sebanyak 65 orang mahasiswa (34,03\%), free WIFI dari kantor saja sebanyak 21 orang mahasiswa $(10,99 \%)$, WIFI berlangganan sebanyak 27 orang mahasiswa $(14,14 \%)$ dan yang berlangganan paket internet dari provider sebanyak 78 orang mahasiswa (40,84\%).

5. Provider yang digunakan saat menggunakan paket internet berlangganan dan atau WIFI berlangganan adalah: Telkomsel 24\%, Indosat sebanyak $12 \%$, XL sebanyak 18\%, Three (3) sebanyak $22 \%$, Smartfren sebanyak $17 \%$, lainnya seperti AXIS, First Media sebanyak 7\%.

6. Mahasiswa memilih provider yang saat ini digunakan dengan alasan: aksesnya cepat sebanyak $46 \%$, biaya murah sebanyak $47 \%$ dan lainnya seperti terpaksa, tidak paham tentang provider, seadanya saat membeli sebanyak $7 \%$.

7. Biaya yang dikeluarkan untuk keperluan internet setiap bulan: tidak mengeluarkan uang sebanyak 2\%, kurang dari Rp. 25.000,sebanyak 10\%, lebih dari Rp. 25.000 sampai dengan Rp. 50.000,- sebanyak 36\%, lebih dari Rp. 50.000,- sampai dengan Rp. 100.000,- sebanyak 35\%, lebih dari Rp 100.000,- sampai dengan Rp. 150.000,- sebanyak 7\%, lebih dari Rp. 150.000,- sampai dengan Rp. 200.000,- sebanyak 6\% dan lebih dari Rp. 200.000,- sebanyak $4 \%$.
8. Mahasiswa dalam mengakses internet untuk keperluan: kuliah sebanyak 33,25\%, pekerjaan sebanyak $13,21 \%$, hiburan sebanyak $25,24 \%$, hobby sebanyak $11,79 \%$, game sebanyak $13,68 \%$ dan lainlain sebanyak 2,83\%.

9. Mahasiswa mengakses internet dalam 1 minggu rata-rata: kurang dari 5 jam sebanyak 31\%, lebih dari 5 jam sampai dengan 10 jam sebanyak 29\%, lebih dari 10 jam sampai dengan 20 jam sebanyak 9\%, lebih dari 20 jam sampai dengan 30 jam sebanyak 12\%, lebih dari 30 jam sampai dengan 40 jam sebanyak 8\% dan yang lebih dari 40 jam sebanyak 11\%.

10. Mahasiswa dalam mengakses internet untuk keperluan kuliah dalam 1 minggu adalah: kurang dari 5 jam sebanyak 60\%, lebih dari 5 jam sampai dengan 10 jam sebanyak 28\%, lebih dari 10 jam sampai dengan 20 jam sebanyak 8\%, lebih dari 20 jam sampai dengan 30 jam sebanyak 1\% dan lebih dari 30 jam sebanyak 3\%.

11. Mahasiswa berpendapat bahwa internet sangat membantu menyelesaikan tugas yang diberikan dosen sebanyak 99\%, dan yang menyatakan tidak sebanyak $1 \%$.

12. Mahasiswa berpendapat bahwa internet sangat membantu mendapatkan nilai lebih baik sebanyak 82\%, dan yang menyatakan tidak membantu mendapatkan nilai lebih baik sebanyak $18 \%$.

13. Mahasiswa berpendapat bahwa pengetahuan lebih mudah diperoleh dari internet sebanyak 95\% dan yang berpendapat dari buku sebanyak 4\% dan yang berpendapat dari lain-lain sebanyak $1 \%$. 
14. Mahasiswa berpendapat bahwa pengetahuan di luar perkuliahan, baik lokal maupun internasional, kebanyakan diperoleh dari: surat kabar sebanyak 19\%, televisi sebanyak $24 \%$ dan dari internet $57 \%$.

15. Persaingan tenaga kerja makin ketat, yang menyatakan mahasiswa saat ini harus mengerti internet $97 \%$, yang menyatakan tidak harus mengerti internet $3 \%$.

16. Peranan internet pada Masyarakat Ekonomi ASEAN, khususnya bagi mahasiswa di masa yang akan datang, yang menyatakan makin mendominasi di segala bidang sebanyak 99\%, yang menyatakan tidak mendominasi sebanyak $1 \%$.

17. Peluang internet bagi mahasiswa saat ini: yang menyatakan menambah pengetahuan secara global sebanyak 57\%, yang menyatakan menambah keahlian sebanyak $28 \%$, yang menyatakan menambah hobby sebanyak 8\%, yang tidak mengisi sebanyak 7\%.

Dari hasil-hasil di atas, nampak bahwa umumnya mahasiswa sebelum masuk kuliah sudah mengenal dan menggunakan internet dan mayoritas sudah menggunakannya lebih dari 4 tahun. Hal ini menunjukkan bahwa kebanyakan mahasiswa sudah menggunakan internet sejak di bangku sekolah pendidikan menengah atau bahkan pendidikan dasar. Sebagian besar perangkat yang digunakan untuk akses internet adalah komputer, smartphone, modem dan kebanyakan mereka berlangganan paket internet yang disediakan oleh provider dan atau memanfaatkan fasilitas free WIFI, baik yang disedikan di tempat kerja maupun di kampus. Pemilihan provider umumnya didasarkan pada biaya murah dan kecepatan akses. Tidak ada satu provider yang sangat dominan dipilih, umumnya antara yang satu dengan yang lain tidak berbeda jauh. Ini berarti bahwa tingkat kompetisi antar provider untuk memberikan layanan internet sangat ketat dan tidak ada satu provider yang sangat dominan dalam memberikan layanan terbaik dari segi akses dan biaya. Biaya yang dikeluarkan mahasiswa per-bulan untuk mendapatkan layanan internet mayoritas antara Rp. 25.000,- sampai dengan Rp. 100.000,-. Umumnya akses internet dimaksudkan untuk keperluan kuliah, hiburan, pekerjaan dan main game. Ada 60\% mahasiswa yang mengakses internet sampai dengan 10 jam per-minggu, dan ada $88 \%$ mahasiswa yang menggunakan internet untuk keperluan kuliah sampai dengan 10 jam per-minggu. Bila dirata-rata berarti per-hari mahasiswa hanya mengakses internet untuk keperluan kuliah kurang dari 1,5 jam. Hal ini menunjukkan pemanfaatan internet untuk keperluan pembelajaran di kalangan mahasiswa masih sangat rendah, walaupun di atas $80 \%$ mahasiswa berpendapat bahwa internet sangat membantu mereka untuk menyelesaikan tugas dari dosen, membantu mendapatkan nilai lebih baik dan menambah pengetahuan. Mahasiswa juga berpendapat kemampuan penguasaan dan pemanfaatan internet dengan baik akan membantu mereka untuk bersaing di pasar kerja dengan tenaga kerja asing dalam rangka menyongsong diberlakukannya Masyarakat Ekonomi ASEAN (MEA). Jadi mahasiswa sebetulnya sudah menyadari pentingnya manfaat internet bagi keberhasilan proses pembelajaran dan peningkatan kompetensi mereka, na- 
mun minat mereka untuk mengakses dan memanfaatkan internet masih sangat rendah, khususnya untuk meningkatkan kapasitas dan kapabilitas mereka. Karenanya perlu mahasiswa dimotivasi untuk memanfaatkan internet khususnya guna keperluan pembelajaran dan peningkatan kompetensi.

\section{KESIMPULAN}

Mahasiswa yang masuk ke perguruan tinggi mayoritas sudah memahami dan memanfaatkan internet sebelumnya, dan umumnya telah menggunakan internet lebih dari 3 tahun. Untuk mengakses internet mereka menggunakan perangkat komputer, smartphone, modem dan perangkat lainnya. Sebagian besar memanfaatkan fasilitas internet dari free WIFI dan berlangganan paket internet yang disediakan oleh provider. Pemilihan provider umumnya didasarkan pada harga paket layanan yang ditawarkan dan kecepatan akses. Tingkat persaingan antar provider sangat ketat dan tidak ada satu provider yang mampu mendominasi dan dianggap paling favorit dalam hal akses dan biaya.

Saat ini pemakaian internet dimaksudkan untuk membantu dalam hal kuliah, hiburan, pekerjaan, main game. Pemakaian dan pemanfaatan internet untuk berbagai hal dan proses pembelajaran di kalangan mahasiswa masih sangat rendah, di mana rata-rata pemakaian internet hanya sekitar 1,5 jam per-hari. Namun mahasiswa meyakini bahwa internet sangat bermanfaat untuk membantu menyelesaikan tugas kuliah, membantu mendapatkan nilai lebih dan menambah pengetahuan. Di samping itu ada keyakinan juga bahwa penguasaan dan pemanfaatan internet akan sangat membantu dalam bersaing pada era globalisasi ASEAN (Masyarakat Ekonomi ASEAN).

\section{SARAN}

1. Mahasiswa sebaiknya diberi bekal pembelajaran yang lebih banyak memanfaatkan intenet.

2. Akses internet di kampus sebaiknya diperbesar kapasitasnya dan kecepatan aksesnya, agar mahasiswa dapat memanfaatkan internet dengan kecepatan tinggi tanpa mengeluarkan biaya.

3. Perlunya memotivasi mahasiswa untuk meningkatkan frekuensi dalam menggunakan internet sebagai sumber belajar agar mahasiswa dapat memperoleh wawasan yang luas dan hasil belajar yang optimal.

4. Para dosen juga harus diberi pelatihan dalam menggunakan internet yang berkaitan dengan proses pembelajaran (e-learning).

\section{DAFTAR KEPUSTAKAAN}

Ardana, Komang, Ni Wayan Mujiati dan Anak Agung Ayu Sriathi, 2009, Perilaku Keorganisasian, Edisi Kedua, Cetakan Pertama, Graha Ilmu, Yogyakarta.

Handoko, T. Hani, 2009, Manajemen Personalia dan Sumber Daya Manusia, BPFE, Yogyakarta.

Harefa, Andrias, 2000, Menjadi Manusia Pembelajar: Pemberdayaan Diri, Transformasi Organisasi dan Masyarakat Lewat Proses Pembelajaran Menuju Indonesia 2045, Kompas Media Nusantara, Jakarta.

Hariandja, Marihot Tua Efendi, 2009, Manajemen Sumber Daya Manusia: Pengadaan, Pengembangan, Pengkompensasian, dan Pening- 
katan Produktivitas Pegawai, Cetakan Kelima, PT Grasindo, Jakarta.

Ishak, 2006, Kebutuhan Informasi Mahasiswa Program Pendidikan Dokter Spesialis (PPDS) FK-UI Dalam Memenuhi Tugas Journal Reading, Pustaha: Jurnal Studi Perpustakaan dan Informasi, Vol. 2, No. 2., hal. 90-101.

Mckinsey Global Institute, 2014, Southeast Asia at The Crossroads: Three Paths to Prosperity.

Moekijat, 2001, Manajemen Kepegawaian, Alumni, Bandung.

Nafisah, Binti Murshid, 2001, Hubungan Penggunaan Media Komputer Berbasis Internet Sebagai Sumber Belajar Dengan Hasil Belajar Siswa Malaysia Di Universitas Negeri Semarang Tahun Akademik 2000/2001, Skripsi, Jurusan Kurikulum Teknologi Pendidikan, Fakultas Ilmu Pendidikan.

Novianto, Iik, 2013, Perilaku Penggunaan Internet di Kalangan Mahasiswa (Studi Deskriptif tentang Perilaku Penggunaan Internet di Kalangan Perguruan Tinggi Negeri (FISIP UNAIR) dengan Perguruan Tinggi Swasta (FISIP UPN) untuk Memenuhi Kebutuhan Informasinya), Jurnal Libri-Net, Vol. 2, No. 1, Universitas Airlangga.

Oetomo, Budi Sutedjo Dharma, 2002, e-Education Konsep, Teknologi dan Aplikasi Internet Pendidikan, Andi, Yogyakarta.
Purbo, Ono W, 2004. Indikator Teknologi Informasi dan Komunikasi Tahun 2001, Pusat Pengkajian dan Penerapan Teknologi Informasi dan Elektronika, Badan Pengkajian dan Penerapan Teknologi Elektronika, Jakarta, tersedia pada http://www.apjii.or.id/dokumentasi/arsip/indikator/si_ti2002.pdf.

Simamora, Henry, 2006, Manajemen Sumber Daya Manusia, Edisi III, Cetakan II, Aditya Media, Yogyakarta.

SMRJ (Organization for Small and Medium Enterprises and Regional Innovation), 2008, Small and Medium Enterprises Development Policies in 6 ASEAN Countries, Organization for Small and Medium Enterprises and Regional Innovation, Toranomon, Japan.

Sulistiyani, Ambar Teguh dan Rosidah, 2009, Manajemen Sumber Daya Manusia: Konsep, Teori dan Pengembangan dalam Konteks Organisasi Publik, Edisi Kedua, Cetakan Pertama, Graha Ilmu, Yogyakarta.

Winardi, 2001, Motivasi dan Pemotivasian Dalam Manajemen, Rajarafindo Persada, Jakarta. 